\title{
Peer Bullying in the Preadolescent Stage: Frequency and Types of Bullying and the Affecting Factors
}

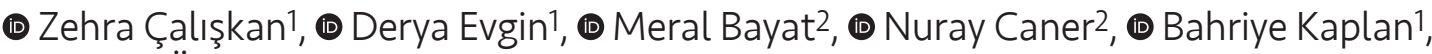 \\ (1) Ahmet Öztürk³, (1) Dilara Keklik²
}

\begin{abstract}
${ }^{1}$ Nevşehir Hacı Bektaş Veli University, Semra ve Vefa Küçük Health School, Department of Child Health and Diseases Nursing, Nevşehir, Turkey 2Erciyes University Faculty of Health Sciences, Department of Child Health and Diseases Nursing, Kayseri, Turkey

${ }^{3}$ Erciyes University Faculty of Medicine, Department of Biostatistic, Kayseri, Turkey
\end{abstract}

\begin{abstract}
Aim: This study was conducted to determine the types, frequencies and the affecting factors of peer bullying among $6^{\text {th }}, 7^{\text {th }}$, and $8^{\text {th }}$ grade students of secondary schools in a city center in Cappadocia.

Materials and Methods: A total of 3.059 students were attending secondary schools in a city center and this study sample consists of 1.288 students. Prior to the study, approval from the ethical council and institute, as well as written consent from students and their families were obtained. Data were collected via individual information forms and the Traditional Peer Bullying scale by the researcher through face-to-face interviews and the data obtained were evaluated by chi-square, single, and multiple logistic regression analysis.

Results: It was determined that the mean age of the students was $12.81 \pm 0.93$ years, of them $51.7 \%$ were girls, $12.0 \%$ did bullying, $15.9 \%$ were exposed to bullying, $52.1 \%$ were exposed to verbal bullying, and $13.4 \%$ were exposed to physical bullying. Multiple logistic regression revealed that the most important factors affecting the bullying of other students were family structure, attitude towards school, and gender; those factors affecting exposure to bullying were attitude toward school, body mass index, and economical status. As the age of the students increased by one year, the likelihood of bullying increased by 1.2 times. Boys were bullied 1.5 times more than girls, and the students of separated parents were bullied 2.7 times more than those whose parents stayed together $(p<0.05)$.

Conclusion: As bullying within schools is an important problem, it may be advisable to take into account the factors affecting bullying (age, gender, economic situation, family structure, attitude toward school, etc.) when conducting studies to prevent bullying in schools.

Keywords: Peer bullying, preadolescent stage, school nursing, school health
\end{abstract}

\section{Introduction}

Bullying, which is an important part of violence in school, is a common problem all over the world (1-6). School bullying is defined as the disruptive behavior of one or more students toward another student or other students with regularity and purpose and without any provocation (7). Bullying is classified into physical (hitting, pushing, spitting), verbal (swearing, assigning nicknames, insulting), relational/social aggression (e.g. social exclusion, rumour spreading, ostracizing and exclusion from games), and cyber bullying (bringing discomfort to others through the use of cell phones and the internet, humiliation) (8-10).

Studies conducted in various countries revealed a bullying prevalence of $8 \%-75 \%$ in schools $(5,11-17)$. In a 
meta-analysis on bullying prevalence with an overall sample of 335.519 youth (12-18 years), the authors found a mean prevalence of $35 \%$ for traditional bullying (16). Of those students who reported being bullied, $13 \%$ were made fun of, called names, or insulted; $12 \%$ were the subject of rumors; $5 \%$ were pushed, shoved, tripped, or spat on; and $5 \%$ were excluded from activities on purpose (17). As the result of the studies in Turkey, it has been determined that the bullying prevalence was between 30-75\% (18-23).

Bullying can affect the psycho-social health of schoolaged children, and this effect may continue throughout the child's life $(5,6,14,24-26)$. Children who are exposed to bullying report problems such as emotional trauma, a negative impact on school life, syndromes such as depression and anxiety, anxiety spectrum disorders such as social phobia and post-traumatic stress disorder, behaviors such as psychotic symptoms and somatic symptoms (e.g., stomach ache, headaches, dizziness, and back pain), sleep disorders, and physical damage in the short term (16,26-30).

When considering the adverse effects of bullying on the personality of students in the long term, low self-esteem, problems in interpersonal relations, and an increase in depression levels have been reported (24-27,31). Bullying exerts negative effects not only on those who are bullied but also on those who bully $(5,31,32)$. The school performance of bullies and their success in their future lives has been determined to be low $(6,32)$. The ability to establish and improve positive relationships with others in their adult years was negatively influenced by chronic bullying, and bullies tended to collect more criminal records than their non-bully counterparts $(32,33)$.

Bullying is clearly an important problem based on a number of studies $(1,2,5,11,13,14,16,25,34-36)$, and the need for preventive programs to be developed quickly has been emphasized (37-39). This problem, which is seen especially among early adolescents $(34,36)$, is an issue that health professionals, such as school nurses, psychologists, psychology consultants, and physicians, and families should address $(1,28,40)$. Besides collaborating with other disciplines, school nurses also play an important role in preventing bullying $(1,4,6,41)$ through primary, secondary, and tertiary precautions (14). School nurses are health professionals who prevent the occurrence of bullying events and provide coordination of care in the process of occurrence, evaluate the effects of bullying on the victim and the bully and also plan and maintain their care $(4,41)$.

It is important to know individual, familial and environmental risk factors related to bullying, to organize training programs on bullying and to ensure participation of students, families, teachers and school staff in these programs (6). Adolescents' tendency to violence; age, gender, socio-economic status, family structure and characteristics have an important role (4). Determining the characteristics of the bullying situation is essential in preventing it.

Therefore, this study was conducted to determine the types and frequencies of peer bullying, as well as the factors that affect bullying, among students in $6^{\text {th }}, 7^{\text {th }}$, and $8^{\text {th }}$ grade classes at secondary schools in a city center of Cappadocia.

\section{Materials and Methods}

This study was conducted in a cross-sectional design. Literature showed that bullying is mostly observed in $6^{\text {th }}, 7^{\text {th }}$ and $8^{\text {th }}$ grade students of primary school $(40,42)$. There were a total of 3.059 students in the $6^{\text {th }}, 7^{\text {th }}$, and $8^{\text {th }}$ grade classes of 11 secondary schools in a city center of Cappadocia. A required study sample of 1.200 was calculated by considering a frequency of $40 \%$ (18) with $95 \%$ probability (alpha $=0.05$ ) and $80 \%$ power; thus, 1.288 students were recruited to participate in this work. The students to be sampled were rated according to schools, grades and gender. According to this, a random batch was determined from the $6^{\text {th }}, 7^{\text {th }}$ and $8^{\text {th }}$ grades of each school. According to the class list in the selected batch, the students were numbered by using a random numbers table. A questionnaire was applied to selected students in a class. The sample of students representing the school and the number of classes are given in Table I.

\section{Ethics}

The study was approved by the Ethics Committee of Nevşehir Hacı Bektaş Veli University (approval number: 2014/01.01). Written consent from the Provincial Directorate for National Education, and written and verbal consent from the students and their families were obtained. The researchers made necessary explanations before the study.

\section{Data Collection}

The researchers made all necessary explanations before the study. Data were collected using an individual information form, which includes the socio-demographic characteristics of the students and their families, and the Traditional Peer Bullying scale (TPBS) via face-to-face meetings. The duration of the survey application was determined as one lesson time (40 minimum) for each 
class by the researchers. The students, teachers and school staff were provided with counselling on bullying.

\section{Measures}

\section{Individual Information form}

The individual information form was developed from literature sources and included 26 questions on the sociodemographic characteristics pertaining to the students such as school studied at, age, gender, grade, parental education status, socio-economic status, number of siblings, attitude toward school and their knowledge about bullying and exposure to bullying. In this study, students' attitude toward school was determined using the closed-ended question "Do you like school?". Income status of students was determined using the question "How do you see the economic situation of your family?".

\section{Traditional Peer Bullying scale}

The TPBS that was modified by Burnukara and Uçanok (19) is composed of two parallel forms that aim to determine the prevalence of both exposure to peer bullying and determining the kinds of bullying attitudes of adolescents in the school environment over the prior 6 months. This scale is composed of 31 items evaluated via a 4-point Likert scale. In each item, "a" measures the victim experience and " $b$ " measures the bully experience of adolescents. The scale includes six sub-dimensions of verbal, relational, physical, attack with personal objects, social exclusion, and threats/ intimidation.

In this study, students were divided in three groups, as bully, victim and bully-victim, according to their scores from the TPBS. Adolescents with scores above the standard deviation of mean peer bullying practice scores (scores received from the bully form) were bullies, those who incurred scores above the standard deviation of mean peer bullying exposure scores (scores from victim form) were victims, and those with scores above the standard deviation of means of both peer bullying practice and peer bullying exposure scores (scores received from both bully and victim forms) were bully/victims. In the study of Burnukara and Uçanok (19), Cronbach's alpha of victim form reached 0.90 but totalled 0.91 for the bully form in the TPBS.

In this study, Cronbach's alpha was found to be 0.92 for the victim form and 0.89 for the bully form.

\section{Statistical Analysis}

Independent variables of the study were as follows; age, gender, economic status, body mass index (BMI) of students and socio-demographic characteristics such as age, gender, occupation and education status of parents. The dependent variables of the study are as follows; the scores obtained from the TPBS. Chi-square, single, and multiple logistic regression analyses were applied, and $p<0.05$ was accepted to indicate a statistically significant difference.

In this study, BMI was calculated [body weight $(\mathrm{kg}) /$ height squared $\left(\mathrm{m}^{2}\right)$ ] after researchers measured the weight and height of the adolescents. The growth curves developed by Neyzi et al. (43) for Turkish children were used in the assessment of $\mathrm{BMI}$. BMI in the $5-14.9^{\text {th }}$ percentile was evaluated as slim, BMI in the $15-84.9^{\text {th }}$ percentile was considered as normal weight, the $85-94.9^{\text {th }}$ percentile was

Table I. Number of students representing schools and classes

\begin{tabular}{|c|c|c|c|c|c|c|c|}
\hline \multirow{2}{*}{ School Name } & \multicolumn{2}{|c|}{$6^{\text {th }}$ grade } & \multicolumn{2}{|c|}{$7^{\text {th }}$ grade } & \multicolumn{2}{|c|}{$8^{\text {th }}$ grade } & \multirow{2}{*}{ Total } \\
\hline & Male & Female & Male & Female & Male & Female & \\
\hline Toki 125. Yıl Ortaokulu & 24 & 23 & 21 & 23 & 16 & 10 & 117 \\
\hline Mihriban Emin Günel Ortaokulu & 23 & 26 & 23 & 26 & 26 & 25 & 149 \\
\hline 75. Yıl Ortaokulu & 27 & 40 & 30 & 30 & 35 & 23 & 185 \\
\hline Damat İbrahim Paşa Ortaokulu & 38 & 47 & 35 & 39 & 28 & 28 & 215 \\
\hline 23 Nisan Ortaokulu & 11 & 10 & 11 & 12 & 10 & 16 & 70 \\
\hline Gazi Ortaokulu & 10 & 4 & 3 & 9 & 7 & 9 & 42 \\
\hline H. Lütfü Pamukcu Ortaokulu & 14 & 25 & 18 & 24 & 22 & 29 & 132 \\
\hline İstiklal Ortaokulu & 23 & 22 & 23 & 23 & 28 & 23 & 142 \\
\hline M. Gülen Ortaokulu & 7 & 11 & 6 & 16 & 10 & 13 & 63 \\
\hline Atatürk Ortaokulu & 23 & 15 & 11 & 13 & 13 & 12 & 87 \\
\hline Cumhuriyet Ortaokulu & 13 & 13 & 20 & 10 & 14 & 16 & 86 \\
\hline Total & 213 & 236 & 201 & 225 & 208 & 204 & 1.288 \\
\hline
\end{tabular}


accepted as overweight, and those with $\mathrm{BMI}$ over the $95^{\text {th }}$ percentile were considered as obese.

\section{Results}

Among the participants, $34.9 \%$ were in the $6^{\text {th }}$ grade class, $37.6 \%$ were 13 years old, $52.2 \%$ were underweight, and $57.5 \%$ had a high socio-economic status. About $92 \%$ of the students lived with their parents, $87.3 \%$ liked school, and $96.2 \%$ did not participate in absenteeism without reason (Table II).

Among the participants, 12\% were bullies and $15.9 \%$ were exposed to bullying (victims). When they experienced bullying, $23.1 \%$ of the students stayed calm and ignored their bully, $16.9 \%$ warned their bully, $16.8 \%$ reported the incident to the school management and their teachers, and $12.1 \%$ responded in the same manner (Table III).

According to the subscales, $52.1 \%$ of the students had been bullied verbally while $13.4 \%$ had been bullied physically (Table III).

Boys, older students, and those who have parents living separately were more bullied than other students $(p<0.05)$, and students who were overweight and had a low socioeconomic status tended to be exposed to more bullying than their counterparts $(p<0.05)$ (Table IV).

The most important factors affecting whether students bullied their peers were family structure [odds ratio (OR) 2.67, 95\% GA 1.47-4.83), attitude toward school (OR 1.86, 95\% GA 1.19-2.13), gender (OR 1.47, 95\% GA 1.02-2.09), and age (OR 1.21, 95\% GA 1.00-1.47); ( $p<0.05)$, and the differences observed were statistically significant. As the age of the students increased by one unit (year), the frequency of bullying situations increased by 1.2 times $(p=0.049)$. Boys were bullied 1.5 times more than girls $(p=0.039)$, and students who did not like school were bullied 1.9 times more than those who did ( $p=0.007)$. Students whose parents had separated were bullied 2.7 times more than those whose mothers and fathers were together $(p=0.001)$ (Table V).

The most important factors affecting exposure to bullying were attitude toward school (OR 2.80, 95\% GA 1.90-4.13), BMI (OR 2.29, 95\% GA 1.27-4.16), economic status (OR 1.51, 95\% GA 1.09-2.09), and age (OR -0.74, 95\% GA 0.63-0.88) ( $p<0.05)$, and the differences observed were statistically significant. As the age of the students decreased by one unit (year), the risk of bullying increased by 0.7 times $(p<0.001)$, and students who were overweight were exposed to bullying 2.3 times more than those who were not $(p=0.006)$. Students who did not like school were exposed to bullying 2.8 times more than those who did $(p<0.001)$, and students with a low socio-economic background were exposed to bullying 2.5 times more than those with a high socio-economic status $(p=0.004)$ (Table V).

The threats/intimidation behaviors of students were mostly affected by gender (OR 2.71, 95\% GA 1.79-4.09), and attitude toward school (OR 1.98, 95\% GA 1.23-3.19) $(p<0.05)$. Also, the most important factor affecting verbal

Table II. The introductive characteristics of the students $(n=1.288)$

\begin{tabular}{|c|c|c|}
\hline Introductive Characteristics & $\mathbf{n}$ & $\%$ \\
\hline \multicolumn{3}{|l|}{ Class level } \\
\hline $6^{\text {th }}$ class & 449 & 34.9 \\
\hline $7^{\text {th }}$ class & 426 & 33.1 \\
\hline $8^{\text {th }}$ class & 413 & 32.0 \\
\hline \multicolumn{3}{|l|}{ Gender } \\
\hline Girl & 667 & 51.8 \\
\hline Boy & 621 & 48.2 \\
\hline \multicolumn{3}{|l|}{ Age } \\
\hline 11 years & 100 & 7.8 \\
\hline 12 years & 379 & 29.4 \\
\hline 13 years & 484 & 37.6 \\
\hline 14- 5 years & 325 & 25.2 \\
\hline \multicolumn{3}{|l|}{ BMI } \\
\hline Low & 672 & 52.2 \\
\hline Normal weight & 551 & 42.8 \\
\hline Overweight and obese & 65 & 5.0 \\
\hline \multicolumn{3}{|l|}{ Economical level } \\
\hline Well & 741 & 57.5 \\
\hline Moderate & 488 & 37.9 \\
\hline Low & 59 & 4.6 \\
\hline \multicolumn{3}{|l|}{ Family situation } \\
\hline Parents are together & 1.186 & 92.0 \\
\hline Parents are separated & 73 & 5.7 \\
\hline Mother or father died & 29 & 2.3 \\
\hline \multicolumn{3}{|l|}{ Attitude toward school } \\
\hline Like & 1.125 & 87.3 \\
\hline Dislike & 163 & 12.7 \\
\hline \multicolumn{3}{|l|}{ Absenteeism } \\
\hline Occurs & 49 & 3.8 \\
\hline Does not occur & 1.239 & 96.2 \\
\hline
\end{tabular}


bullying was attitude toward school (OR 1.64, 95\% GA 1.17-2.30) $(p<0.05)$. The most important factors affecting physical bullying were gender (OR 2.39, 95\% GA 1.70-3.36) and attitude toward school (OR 2.01, 95\% GA 1.33-3.04) $(p<0.05)$. Absenteeism, which was the most important factor in relational bullying, was found to be statistically significant (OR -0.47, 95\% GA 0.22-1.00) ( $p<0.05)$. The most important factors affecting attacks with personal objects were gender (OR 2.74, 95\% GA 1.61-4.67) and absenteeism (OR -0.41, 95\% GA 0.16-1.00) $(p<0.05)$. Attitude toward school was found to be the most important factor

Table III. Situations of students for bullying and exposure to bullying and their reactions when they experience bullying behaviours according to the scale points

\begin{tabular}{|c|c|c|}
\hline TPBS means of students & $\mathbf{n}$ & $\%$ \\
\hline \multicolumn{3}{|l|}{ Situation of bullying } \\
\hline Bullies others & 154 & 12.0 \\
\hline Does not bully others & 1.134 & 88.0 \\
\hline \multicolumn{3}{|l|}{ Situation of exposure to bullying } \\
\hline Exposed to bullying & 205 & 15.9 \\
\hline Not exposed to bullying & 1.083 & 84.1 \\
\hline \multicolumn{3}{|l|}{ Bullying sub-dimensions** } \\
\hline Threats/Intimidation & 118 & 9.2 \\
\hline Physical bullying & 173 & 13.4 \\
\hline Verbal bullying & 670 & 52.1 \\
\hline Relational bullying & 128 & 9.9 \\
\hline Attacking with personal items & 69 & 5.4 \\
\hline Social exclusion & 153 & 11.9 \\
\hline \multicolumn{3}{|l|}{ Given Reactions* } \\
\hline Staying calm, not minding, not caring & 297 & 23.1 \\
\hline Telling to the teacher & 217 & 16.8 \\
\hline Warning & 218 & 16.9 \\
\hline Doing the same & 156 & 12.1 \\
\hline Beating & 92 & 7.1 \\
\hline Getting sad/crying & 87 & 6.8 \\
\hline Being angry & 26 & 2.0 \\
\hline Asking the reason & 21 & 1.6 \\
\hline Other*** & 71 & 5.6 \\
\hline No answer & 208 & 16.2 \\
\hline
\end{tabular}

*More than one answer was taken. Percentage was calculated on the basis of ' $n$ ', ${ }^{* *}$ In bullying sub-dimensions; only the numbers and percentages of bullying are given, ${ }^{* * *}$ Other (Telling the family, break up, solacement, protecting the victim, finding the truth, laughing, apologizing, not looking at his/her face)

TPBS: Traditional Peer Bullying scale influencing social exclusion [(OR 1.75, 95\% GA 1.12-(-2.72)] $(p<0.05)$ (Table VI).

Boys were exposed to threats/intimidation behaviors 2.7 times more, physical bullying behaviors 2.4 times more, and attacks with personal objects 2.7 times more than girls $(p<0.001)$. Students who did not like going to school showed threats/intimidation behaviors 2 times more $(p=0.005)$, verbal bullying 1.6 times more $(p=0.004)$, physical bullying 2 times more $(p=0.001)$, and social exclusion 1.8 more $(p=0.013)$ than students who liked going to school (Table $\mathrm{VI})$. In the victim form; girls were exposed to verbal bullying 0.7 times more, relational bullying 0.6 times more, and social exclusion 0.7 times more than boys; by contrast, boys were exposed to threats/intimidation 1.6 times more than girls $(p<0.05)$. Students with a higher BMI were exposed to verbal bullying 2 times and social exclusion 2.5 times more than those with a lower BMI $(p<0.05)$. Students who did not like school were exposed to threats/intimidation behaviors 2 times more, verbal bullying 1.9 times more, physical bullying 2 times more, relational bullying 3 times more, attacks with, personal objects 2.8 times more, and social exclusion 1.7 more than those who liked school $(p<0.05)$ (Table VI).

Students with mothers who graduated from secondary or high school were exposed to intimidation and threatening behaviors about 0.6 times less than those whose mothers graduated from primary school only $(p<0.05)$. Students with a low socio-economic status were exposed to threatening and intimidating behaviors 2.1 times more, verbal bullying 2.1 times more, and social exclusion 2.2 times more than those with a high socio-economic status $(p<0.05)$ (Table VI).

\section{Discussion}

The findings of the study conducted in order to determine the types and frequencies of peer bullying, as well as the factors that affect bullying, among students in $6^{\text {th }}, 7^{\text {th }}$, and $8^{\text {th }}$ grade classes at secondary schools are discussed below.

Some studies have found bully rates of between $2 \%$ and $18 \%$, victim rates between $4.8 \%$ and $26 \%$, and bully-victim rates between $2 \%$ and $24 \%(7,18,19,35,44,45)$. In this study, $12 \%$ of the students bullied, $15.9 \%$ were exposed to bullying (victims), and $15.1 \%$ were bully/victims; thus, bullying in schools should be considered an important problem (Table III). Hesapçığlu et al. (20) found that $23.4 \%$ of students were victims of bullying, $28.5 \%$ were bullies and $13.4 \%$ were both bullies and victims.

According to subdimensions, it was found that students performed mostly verbal bullying, other studies 
show that students are exposed to mostly verbal bullying $(18,26,28,35,44,46,47)$. Students exposed to bullying behaviors reported trying to stay calm, ignoring their bully $(23.1 \%)$, warning their bully $(16.9 \%)$, talking to their school principal and teachers (16.8\%), and bullying back (12.1\%) in response to being bullied (Table III). In other studies, participants stated that when they were exposed to bullying, they reacted by thinking of this behavior as a

\begin{tabular}{|c|c|c|c|c|c|c|c|c|}
\hline \multirow{2}{*}{$\begin{array}{l}\text { Introductive } \\
\text { characteristics }\end{array}$} & \multicolumn{2}{|l|}{ Bully } & \multicolumn{2}{|c|}{ Non-bully } & \multicolumn{2}{|c|}{ Exposed to bullying } & \multicolumn{2}{|c|}{ Not exposed to bullying } \\
\hline & $n$ & $\%$ & $n$ & $\%$ & $n$ & $\%$ & $n$ & $\%$ \\
\hline \multicolumn{9}{|l|}{ Gender } \\
\hline Girl & 60 & 9.0 & 607 & 91.0 & 111 & 16.6 & 556 & 83.4 \\
\hline \multirow[t]{2}{*}{ Boy } & 81 & 13.0 & 540 & 87.0 & 87 & 14.0 & 534 & 86.0 \\
\hline & \multicolumn{4}{|c|}{$\chi^{2}=5.405 \quad p=0.020$} & \multicolumn{4}{|c|}{$\chi^{2}=1.712 \quad p=0.191$} \\
\hline \multicolumn{9}{|l|}{ Age } \\
\hline 11 years & 8 & 8.0 & 92 & 92.0 & 19 & 19.0 & 81 & 81.0 \\
\hline 12 years & 41 & 10.8 & 338 & 89.2 & 77 & 20.3 & 302 & 79.7 \\
\hline 13 years & 46 & 9.5 & 438 & 90.5 & 65 & 13.4 & 419 & 86.6 \\
\hline 14 years & 37 & 12.2 & 266 & 87.8 & 62 & 10.6 & 271 & 89.4 \\
\hline \multirow[t]{2}{*}{15 years } & 9 & 40.9 & 13 & 59.1 & 5 & 22.7 & 17 & 77.3 \\
\hline & \multicolumn{4}{|c|}{$\chi^{2}=22.687 \quad p<0.001$} & \multicolumn{4}{|c|}{$\chi^{2}=15.843 \quad p=0.003$} \\
\hline \multicolumn{9}{|l|}{ BMI } \\
\hline Low & 66 & 9.8 & 606 & 90.2 & 104 & 15.5 & 568 & 84.5 \\
\hline Normal weight & 66 & 12.0 & 485 & 88.0 & 75 & 13.6 & 476 & 86.4 \\
\hline \multirow[t]{2}{*}{ Overweight } & 9 & 13.8 & 56 & 86.2 & 19 & 29.2 & 46 & 70.8 \\
\hline & \multicolumn{4}{|c|}{$\chi^{2}=2.035 \quad p=0.362$} & \multicolumn{4}{|c|}{$\chi^{2}=10.914 \quad p=0.004$} \\
\hline \multicolumn{9}{|l|}{ Economical level } \\
\hline Well & 78 & 10.5 & 663 & 89.5 & 93 & 12.6 & 648 & 87.4 \\
\hline Moderate & 56 & 11.5 & 432 & 88.5 & 88 & 18.0 & 400 & 82.0 \\
\hline \multirow[t]{2}{*}{ Low } & 7 & 11.9 & 52 & 88.1 & 17 & 28.8 & 42 & 71.2 \\
\hline & \multicolumn{4}{|c|}{$\chi^{2}=3.369 \quad p=0.498$} & \multicolumn{4}{|c|}{$\chi^{2}=15.384 \quad p<0.001$} \\
\hline \multicolumn{9}{|l|}{ Attitude to school } \\
\hline Like & 112 & 10.0 & 1013 & 90.0 & 150 & 13.3 & 975 & 86.7 \\
\hline \multirow[t]{2}{*}{ Dislike } & 29 & 17.8 & 134 & 82.2 & 48 & 29.4 & 115 & 70.6 \\
\hline & \multicolumn{4}{|c|}{$\chi^{2}=8.967 \quad p=0.003$} & \multicolumn{4}{|c|}{$\chi^{2}=28.418 \quad p<0.001$} \\
\hline \multicolumn{9}{|l|}{ Family situation } \\
\hline Parents are together & 122 & 10.3 & 1064 & 89.7 & 184 & 15.5 & 1002 & 84.5 \\
\hline \multirow[t]{2}{*}{ Parents are seperated } & 19 & 18.6 & 83 & 81.4 & 14 & 13.7 & 88 & 86.3 \\
\hline & $\chi^{2}=6.702$ & $p=0.010$ & & & $\chi^{2}=0.231$ & $p=0.631$ & & \\
\hline Absenteeism & & & & & & & & \\
\hline Occurs & 8 & 16.3 & 41 & 83.7 & 11 & 22.4 & 38 & 77.6 \\
\hline Does not occur & 133 & 10.7 & 1106 & 89.3 & 187 & 15.1 & 1052 & \\
\hline & $\chi^{2}=1.512$ & $p=0.219$ & & & $\chi^{2}=1.961$ & $p=0.161$ & & \\
\hline
\end{tabular}


joke, by not minding the mockings, by responding verbally or physically or by avoiding, by not going to school, by sharing this with their closest friends, families, teachers, and school management $(46,47)$. Verbal bullying is very common in schools and society because verbal bullying is not typically considered a type of bullying which may cause serious results and sometimes is supported by individual's environment and family.

There are factors such as age and gender in bullying. These changes in bullying rates can be thought to be caused by differences in demographic and social risk factors (such as age, gender, income status, family structure, family attitude, societal values, ethos) (8). In one study, the most frequently

Table V. The students' bullying and exposure to bullying according to their introductive characteristics

\begin{tabular}{|c|c|c|}
\hline \multirow{3}{*}{$\begin{array}{l}\text { Introductive } \\
\text { characteristics }\end{array}$} & \multicolumn{2}{|c|}{$\begin{array}{l}\text { Multiple binary logistic regression analyses } \\
\text { (model: backward wald) }\end{array}$} \\
\hline & Bullied & Exposed to bullying \\
\hline & OR $(95 \% \mathrm{Cl})$ & OR $(95 \% \mathrm{Cl})$ \\
\hline Age (years) & $\begin{array}{l}1.21(1.00-1.47) \\
p=0.049\end{array}$ & $\begin{array}{l}-0.74(0.63-0.88) \\
p<0.001\end{array}$ \\
\hline \multicolumn{3}{|l|}{ Gender } \\
\hline Girl & 1 & - \\
\hline Boy & $\begin{array}{l}1.47(1.02-2.09) \\
p=0.039\end{array}$ & - \\
\hline \multicolumn{3}{|l|}{ BMI } \\
\hline Weak 1 & - & 1 \\
\hline Normal & - & $\begin{array}{l}-0.94(0.67-1.31) \\
p=0.713\end{array}$ \\
\hline Overweight & - & $\begin{array}{l}2.29(1.27-4.16) \\
p=0.006\end{array}$ \\
\hline \multicolumn{3}{|l|}{ Like to school } \\
\hline Like & 1 & 1 \\
\hline Not like & $\begin{array}{l}1.86(1.19-2.13) \\
p=0.007\end{array}$ & $\begin{array}{l}2.80(1.90-4.13) \\
p<0.001\end{array}$ \\
\hline \multicolumn{3}{|l|}{ Economical level } \\
\hline Well 1 & - & 1 \\
\hline Moderate & - & $\begin{array}{l}1.51(1.09-2.09) \\
p=0.013\end{array}$ \\
\hline Low & - & $\begin{array}{l}2.53(1.35-4.75) \\
p=0.004\end{array}$ \\
\hline \multicolumn{3}{|c|}{ Familial situation } \\
\hline $\begin{array}{l}\text { Parents are } \\
\text { together } 1\end{array}$ & 1 & - \\
\hline $\begin{array}{l}\text { Parents are } \\
\text { separated }\end{array}$ & $\begin{array}{l}2.67(1.47-4.83) \\
p=0.001\end{array}$ & - \\
\hline
\end{tabular}

OR: Odds ratio, Cl: Confidence interval, BMI: Body mass index reported reason for bullying was physical weakness, but also being fat and being poor were among the other causes (48). In this study, boys, older students, and those who have parents living separately were more bullied than other students $(p<0.05)$, and students who were overweight and had a low socio-economic status tended to be exposed to more bullying than their counterparts $(p<0.05)$ (Table IV). These findings are similar to other studies in the literature $(18,19,22,23,32,34,37,39)$.

The present study found that boys were more likely to be victims of bullying than girls $(p<0.05)$ (Table IV,V). In various studies on the relationship between bullying and gender, boys were observed to be bullied and exposed to bullying to a greater extent than girls $(26,39,44)$.

In this study, boys tended to engage in threats/ intimidation, physical bullying, and attacking with personal objects more often than girls. By comparison, girls were more exposed to verbal and relational bullying and social exclusion than boys (Table VI). Similar studies revealed that boys were physically bullied more than girls and that boys were at higher risk of bullying than girls $(22,26,49)$. Verbal bullying through mocking, relational attacks, and social exclusion were observed more frequently among girls than boys $(22,38,49)$. The results of this study are similar to those in the literature. Thus, in school, boys may be at higher risk of physical bullying than girls and the latter may be at higher risk of verbal bullying than the former.

In this study, age was determined as a factor affecting bullying and exposure to bullying (Table IV). As the age of students increased by one unit (year), the frequency of bullying situations increased (Table V). While one previous study demonstrated that negative behaviors related to bullying decreased with increasing age (22), two other studies revealed that bullying increased with age, similar to the results of the present work (24). Also, in a study investigating bullying among classes, it was found that the students who were in the $8^{\text {th }}$ class bullied more than the other students in the $6^{\text {th }}$ and $7^{\text {th }}$ grade classes; by contrast, students in the $6^{\text {th }}$ grade class were more exposed to bullying than students in the $7^{\text {th }}$ and $8^{\text {th }}$ grade classes (46). Therefore, teaching students efficient problem-solving methods and empathy prior to the age when the risk of bullying increases could contribute to decreasing future bullying behaviors.

Students who were overweight were more exposed to bullying than those who were not $(p=0.006)$ (Table $\mathrm{IV}, \mathrm{V})$; these students reported verbal bullying and social exclusion $(p<0.05)($ Table $\mathrm{VI})$. A previous study indicated 
Table VI. The mean scores from subdimensions of bully and victim scales of the students according to their introductive characteristics

\begin{tabular}{|l|l|l|l|l|l|l|}
\hline \multirow{2}{*}{$\begin{array}{l}\text { Introductive } \\
\text { characteristics }\end{array}$} & \multicolumn{4}{|l}{ Multiple binary logistic regression analyses (model: backward wald) } \\
\cline { 2 - 7 } & $\begin{array}{l}\text { Threats/ } \\
\text { intimidation }\end{array}$ & Verbal bullying & Physical bullying & Relational bullying & $\begin{array}{l}\text { Attack with } \\
\text { personal objects }\end{array}$ & Social exclusion \\
\cline { 2 - 6 } & OR $(95 \% \mathrm{CI})$ & OR $(95 \% \mathrm{Cl})$ & OR $(95 \% \mathrm{Cl})$ & OR $(95 \% \mathrm{Cl})$ & OR $(95 \% \mathrm{Cl})$ & OR $(95 \% \mathrm{Cl})$ \\
\hline
\end{tabular}

Bully form gender (1)

\begin{tabular}{|l|l|l|l|l|l|l|}
\hline Girl & 1 & - & 1 & - & 1 & - \\
\hline Boy & $\begin{array}{l}2.71(1.79-4.09) \\
p<0.001\end{array}$ & - & $\begin{array}{l}2.39(1.70-3.36) \\
p<0.001\end{array}$ & - & $\begin{array}{l}2.74(1.61-4.67) \\
p<0.001\end{array}$ & - \\
\hline
\end{tabular}

\section{Absenteeism}

\begin{tabular}{l|l|}
\hline Occurs & - \\
\hline Does not occur & - \\
\hline
\end{tabular}

\begin{tabular}{|l|l|l|}
\hline- & - & - \\
\hline- & - & 1 \\
& $-0.47(0.22-1.00)$ \\
$p=0.049$
\end{tabular}

\begin{tabular}{|l|l|}
\hline & - \\
\hline 1 \\
$-0.41(0.16-1.00)$ & - \\
$p=0.049$ & \\
\hline
\end{tabular}

Attitude to school (1)

\begin{tabular}{|l|l|l|l|l|l|l|}
\hline Like & 1 & 1 & 1 & - & - & 1 \\
\hline Dislike & $\begin{array}{l}1.98(1.23-3.19) \\
p=0.005\end{array}$ & $\begin{array}{l}1.64(1.17-2.30) \\
p=0.004\end{array}$ & $\begin{array}{l}2.01(1.33-3.04) \\
p=0.001\end{array}$ & - & - & $\begin{array}{l}1.75(1.12-2.72) \\
p=0.013\end{array}$ \\
\hline
\end{tabular}

Victim form

\begin{tabular}{|c|c|c|c|c|c|c|}
\hline \multirow[t]{2}{*}{ Variables } & $\begin{array}{l}\text { Threats/ } \\
\text { intimidation }\end{array}$ & Verbal bullying & Physical bullying & Relational bullying & $\begin{array}{l}\text { Attack with } \\
\text { personal objects }\end{array}$ & Social exclusion \\
\hline & OR $(95 \% \mathrm{Cl})$ & OR $(95 \% \mathrm{Cl})$ & OR $(95 \% \mathrm{CI})$ & OR $(95 \% \mathrm{CI})$ & OR $(95 \% \mathrm{CI})$ & OR (95\% CI) \\
\hline Age (years) & - & - & $\begin{array}{l}0.80(0.69-0.94) \\
p=0.007\end{array}$ & $\begin{array}{l}-0.83(0.72-0.97) \\
p=0.018\end{array}$ & - & $\begin{array}{l}-0.78(0.67-0.92) \\
p=0.003\end{array}$ \\
\hline
\end{tabular}

Gender (1)

\begin{tabular}{|l|l|l|l|l|l|l|}
\hline Girl & 1 & 1 & - & 1 & & 1 \\
\hline Boy & $1.60(1.18-2.17)$ & $\begin{array}{l}-0.72(0.54-0.95) \\
p=0.021\end{array}$ & & $\begin{array}{l}-0.58(0.44-0.78) \\
p<0.001\end{array}$ & - & $-0.68(0.50-0.92)$ \\
& $p=0.003$ & 0.012 & $p$ \\
\hline
\end{tabular}

BMI (1)

\begin{tabular}{|l|l|l|l|l|l|l|}
\hline Low 1 & - & 1 & - & - & - & 1 \\
\hline Normal & - & $\begin{array}{l}1.40(1.04-1.86) \\
p=0.024\end{array}$ & - & - & - & $\begin{array}{l}-0.98(0.72-1.35) \\
p=0.910\end{array}$ \\
\hline Overweight & - & $\begin{array}{l}2.10(1.16-3.81) \\
p=0.015\end{array}$ & - & - & - & $\begin{array}{l}2.48(1.40-4.40) \\
p=0.002\end{array}$ \\
\hline
\end{tabular}

Attitude towards school (1)

\begin{tabular}{|l|l|l|l|l|l|l|}
\hline Like & 1 & 1 & 1 & 1 & 1 & 1 \\
\hline Dislike & $2.00(1.35-2.96)$ & $\begin{array}{l}1.86(1.28-2.71) \\
p=0.001\end{array}$ & $\begin{array}{l}1.98(1.34-2.94) \\
p=0.001\end{array}$ & $\begin{array}{l}2.99(2.08-4.31) \\
p<0.001\end{array}$ & $\begin{array}{l}2.77(1.86-4.13) \\
p<0.001\end{array}$ & $\begin{array}{l}1.70(1.13-2.53) \\
p=0.011\end{array}$ \\
\hline
\end{tabular}

Mother education (1)

\begin{tabular}{|l|l|l|l|l|l|l|}
\hline Primary school 1 & 1 & - & - & - & - & - \\
\hline $\begin{array}{l}\text { Secondary-high } \\
\text { school }\end{array}$ & $\begin{array}{l}-0.60(0.43-0.83) \\
p=0.002\end{array}$ & - & - & - & - & - \\
\hline University & $\begin{array}{l}-0.85(0.48-1.51) \\
p=0.570\end{array}$ & - & - & - & - & - \\
\hline
\end{tabular}




\begin{tabular}{|c|c|c|c|c|c|c|}
\hline \multirow{3}{*}{$\begin{array}{l}\text { Introductive } \\
\text { characteristics }\end{array}$} & \multicolumn{6}{|c|}{ Multiple binary logistic regression analyses (model: backward wald) } \\
\hline & $\begin{array}{l}\text { Threats/ } \\
\text { intimidation }\end{array}$ & Verbal bullying & Physical bullying & Relational bullying & $\begin{array}{l}\text { Attack with } \\
\text { personal objects }\end{array}$ & Social exclusion \\
\hline & OR $(95 \% \mathrm{Cl})$ & OR $(95 \% \mathrm{Cl})$ & OR $(95 \% \mathrm{Cl})$ & OR $(95 \% \mathrm{Cl})$ & OR $(95 \% \mathrm{Cl})$ & OR $(95 \% \mathrm{Cl})$ \\
\hline \multicolumn{7}{|c|}{ Economical level (1) } \\
\hline Well 1 & 1 & 1 & - & - & 1 & 1 \\
\hline Moderate & $\begin{array}{l}1.58(1.15-2.19) \\
p=0.005\end{array}$ & $\begin{array}{l}1.40(1.04-1.86) \\
p=0.024\end{array}$ & - & - & $\begin{array}{l}1.50(1.06-2.11) \\
p=0.021\end{array}$ & $\begin{array}{l}1.63(1.20-2.21) \\
p=0.002\end{array}$ \\
\hline Low & $\begin{array}{l}2.12(1.12-4.01) \\
p=0.020\end{array}$ & $\begin{array}{l}2.10(1.16-3.81) \\
p=0.015\end{array}$ & - & - & $\begin{array}{l}1.78(0.88-3.62) \\
p=0.109\end{array}$ & $\begin{array}{l}2.19(1.17-4.11) \\
p=0.014\end{array}$ \\
\hline
\end{tabular}

OR: Odds ratio, $\mathrm{Cl}$ : Confidence interval, BMI: Body mass index

that obese or overweight students were more exposed to bullying than those who were not overweight $(p<0.05)$ (49-51).

In this study, students with a low economic status were more exposed to bullying than those with higher economic backgrounds $(p=0.003$ ) (Table IV,V). Students with a low economic status were mainly exposed to threats/intimidation, verbal bullying, and social exclusion (Table VI). In a previous study, a positive relationship between exposure to bullying situations and a low socioeconomic status and a negative relationship between bullying and a high socio-economic status were found (52). Another study revealed that individuals with economic trouble in the family reported higher rates of bullying $(p<0.01)$ and exposure to bullying $(p<0.001)$ than those without (53). Thus, according to the results of several studies, children with a low socio-economic status are at higher risk of being bulled than those with a higher socioeconomic status. The school counselor, school nurse, and teachers should consider this situation.

In this study, students who did not like school bullied more and were exposed to more bullying than those who liked school (Tables IV,V,VI). Similar to our results, those students who did not like the school bullied and were exposed to bullying $(p<0.05)$ more than the others in Ergün's (53) work. A strong positive relationship between liking school and being a victim was observed, attendance to school among bully students was less and they had higher absenteeism mostly. Not liking school and high levels of absenteeism can thus be considered as risk factors of being bullied.

Besides personal reasons, some important reasons to explain violent events at school include a low socioeconomic status and a separated family unit $(32,49,54)$. In a systematic review, children without a traditional family structure were found to be at a higher risk of bullying compared with children with such a structure (55). In our study, similarly to the literature, students whose father and mother were separated were bullied more often than those whose parents were together $(p=0.001)$ (Table IV,V). Yang et al. (56) found that children with a single parent were bullied more than others $(p<0.001)$.

In this study, students whose mothers had graduated from secondary and high school were exposed to threats/ intimidation to a lesser extent than those whose mothers had graduated only from primary school $(p<0.05)$ (Table VI). In another study, students whose mothers had a high level of education were at less risk of being bullied than those with a low level of education (57).

\section{Study Limitations}

One limitation of this study is that the research was done with students in only one city in Turkey where the data were collected. Therefore, the results obtained without research can be generalized to students in this research group.

\section{Conclusions}

Bullying behaviors among school-aged children occurred more frequently among boys, students who did not like school, those who lived with single parents, and those who were exposed to bullying. Exposure to bullying was affected by being overweight, not liking one's school, and a poor economic status. It could be suggested that these students and their families should be regularly followed up concerning bullying, and programs to prevent bullying should be developed and disseminated among students, teachers, and parents. 


\section{Acknowledgments}

This study was announced as verbal announcement at European Academy of Pediatric Societies EAPS, Barcelona, Spain, October 17-21, 2014. This study was supported by Nevşehir Hacı Bektaş Veli University Scientifical Research Project Unit with the project numbered NEÜBAP14S18. There was no conflict between The Scientific World Journal and the authors during the production and writing up of the research. The authors guarantee that neither all nor part of this manuscript has been published elsewhere in its present form, in another publication or under a different title by either these authors or other authors.

\section{Ethics}

Ethics Committee Approval: The study was approved by the Ethics Committe of Nevşehir Hacı Bektaş Veli University (approval number: 2014/01.01).

Informed Consent: Written and verbal consent from the students and their families were obtained.

Peer-review: Externally and internally peer-reviewed.

\section{Authorship Contributions}

Concept: Z.Ç., D.E., M.B., Design: Z.Ç., D.E., M.B., Data Collection or Processing: D.E., N.C., B.K., D.K., Analysis or Interpretation: D.E., A.Ö., Literature Search: D.E., N.C., Writing: Z.Ç., D.E., M.B.

Conflict of Interest: No conflict of interest was declared by the authors.

Financial Disclosure: This study was supported by Nevşehir Hacı Bektaş Veli University Scientifical Research Project Unit with the project numbered NEÜBAP14S18.

\section{References}

1. Liu J, Graves N. Childhood bullying: A review of constructs, concepts, and nursing implications. Public Health Nurs 2011;28:556-68.

2. Rigby K, Johnson K. The prevalence and effectiveness of antibullying strategies employed in Australian schools. Adelaide: University of South Australia, 2016.

3. Holt MK, Green JG, Tsay-Vogel M, Davidson I, Brown C. Multidisciplinary approaches to research on bullying in adolescence. Adolescent Res Rev 2016;2:1-10.

4. Coşkun S, Bebiş $\mathrm{H}$. The effect of violence to the school health and nursing. Cumhuriyet Nurs I 2014;3:15-23.

5. Brank EM, Hoetger LA, Hazen KP. Bullying. Annu Rev of Law and Soc Sci 2012;8:213-30.

6. Karataş H, Öztürk C. Approach to bullying with social cognitive theory. DEUHEFED 2009;2:61-74.

7. Olweus DA. A profile of bullying at school. Educational Leadership 2003;60:12.
8. Vanderbilt $D$, Augustyn M. The effects of bullying. Paediatrics and child health 2010;20:315-20.

9. Shetgiri R. Bullying and victimization among children. Adv Pediatr 2013;60:33-51.

10. Menesini E, Salmivalli C. Bullying in schools: The state of knowledge and effective interventions. Psychol Health Med 2017;22:240-53.

11. Wei HS, Chang HH, Chen JK. Bullying and victimisation among Taiwanese students in special schools. Int I Disabil Dev and Educ 2016;63:246-59.

12. Wu J, He Y, Lu C, et al. Bullying behaviors among Chinese schoolaged youth: A prevalence and correlates study in Guangdong province. Psychiatry Res 2014;225:716-22.

13. Inchley I, Currie D, Young T, et al. Growing up unequal: Gender and socioeconomic differences in young people's health and well-being. HBSC International Report From the 2013/2014 survey. WHO, Health Policy Children and Adolescents 2016;7:197-205.

14. Zych I, Ortega-Ruiz R, Del Rey R. Systematic review of theoretical studies on bullying and cyberbullying: Facts, knowledge, prevention, and intervention. Aggress Violent Behav 2015;23:121.

15. Elgar F), McKinnon B, Walsh SD, et al. Structural deter-minants of youth bullying and fighting in 79 countries. I Adolesc Health 2015;57:643-50.

16. Modecki KL, Minchin J, Harbaugh AG, Guerra NG, Runions KC. Bullying prevalence across contexts: A meta-analysis measuring cyber and traditional bullying. I Adolesc Health 2014;55:602-11.

17. National Center for Education Statistics. (2016). Indicators of School Crime and Safety: 2016. U.S. Department of Education. https://nces.ed.gov/pubs2017/2017064.pdf Available date: 20.11.2018

18. Kapçı EG. The relationship between exposed to bullying and frequency with depression, anxiety and self respect of primary school students. Ankara University Education Sciences Faculty I 2004;37:1-13.

19. Burnukara P, Uçanok Z. Peer bullying at early and mid adolescent: Places that it occured and coping methods. Turk Psikol Derg 2012;15:68-82

20. Tural Hesapçıoğlu S, Meraler H, Yeşilova Ercan F. Bullying in schools and its relation with depressive symptoms, selfesteem, and suicidal ideation in adolescents. Anat / Psychiatr 2018;19:210-6

21. Tıpırdamaz-Sipahi H. Factors affecting and accompanying peer bullying in primary school 6th and 7th grade students in Bornova, Izmir. (Doctorate Thesis). Ege University Health Sciences Institute, Izmir, 2008. Available date: 23.12.2018.

22. Yurtal F, Cenkseven F. The generality and nature of bullying at primary schools. Turkish Psychologic Guidance and Councelling | 2007;3:1-13.

23. Pişkin M. Examination of peer bullying among primary and middle school children in Ankara. Educ Sci 2010;35:175-89.

24. James A. School bullying. Research Briefings 2010. Available date: 14.03.2017. http://www.nspcc.org.uk/inform/research/ briefings/school_bullying_pdf_wdf73502

25. Graham S. Victims of bullying in schools. Theory Pract 2016;55:136-44 
26. Pells K, Portela MJO, Revollo PE. Experiences of peer bullying among adolescents and associated effects on young adult outcomes: Longitudinal evidence from Ethiopia, India, Peru and Viet Nam. Innocenti Discussion Paper 2016;3:1-61.

27. Skybo T. Witnessing violence: Biopsychosocial impact on children. Pediatr Nurs 2005;31:263-70.

28. Arslan-Özdinçer S, Savaşer S. In the context of human rights and children rigths bullying at school. Istanbul University Florence Nightingale Nurs | 2008;16:65-70.

29. Moore SE, Norman RE, Suetani S, Thomas H), Sly PD, Scott JG. Consequences of bullying victimization in childhood and adolescence: A systematic review and meta-analysis. World I Psychiatr 2017;7:60-76.

30. Wolke D, Lereya ST. Long-term effects of bullying. Arch Dis Child 2015;100:879-85

31. Karatas H, Ozturk C. Relationship between bullying and health problems in primary school children. Asian Nurs Res (Korean Soc Nurs Sci) 2011;5:81-7.

32. Pişkin M. School bullying: Definiton, types and relational factors and measures. Educ Sci Theor Pract 2002;2:531-62.

33. Maliki AE, Asagwara CG, Ibu JE. Bullying problems among school children. ) Hum Ecol 2009;25:209-13.

34. Jansen PW, Verlinden $M$, Dommisse-van Berkel $A$, et al. Prevalence of bullying and victimization among children in early elementary school: Do family and school neighbourhood socioeconomic status matter? BMC Public Health 2012;12:494.

35. Maïano C, Aimé A, Salvas MC, Morin AJ, Normand CL. Prevalence and correlates of bullying perpetration and victimization among school-aged youth with intellectual disabilities: A systematic review. Res Dev Disabil 2016;49:181-95.

36. Craig W, Harel-Fisch Y, Fogel-Grinvald $H$, et al. Cross-national profile of bullying and victimization among adolescents in 40 countries. Int J Public Health 2009;54:216-24.

37. Evgin $D$. The effect of nursing interventions based on behavioral system model on peer bullying. (Doctorate Thesis). Erciyes University Health Sciences Institute, Kayseri, 2015. Available date: 23.09.2015. https://tez.yok.gov.tr/UlusalTezMerkezi/ tezSorguSonucYeni.jsp

38. Vessey IA, O'Neill KM. Helping students with disabilities better address teasing and bullying situations A MASNRN study. I Sch Nurs 2011;27:139-48.

39. Albayrak $\mathrm{S}$. The effect of preventing bullying program at school on decrease bullying. (Doctorate Thesis). Marmara University Health Sciences Institute, İstanbul, 2012. Available date: 15.08.2015.file:///C:/Users/server/Downloads/310121.pdf

40. Galitz T, Robert D. Governing bullying through the new public health model: A foucaultian analysis of a school anti-bullying programme. Crit Public Health 2014;24:182-95.

41. King K. Violence in the school setting: A school nurse perspective. Online J Issues Nurs 2014;19:4.
42. Gini G, Pozzoli T. Association between bullying and psychosomatic problems: A meta-analysis. Pediatrics 2009;123:1059-65.

43. Neyzi $O$, Günöz H, Furman $A$, et al. Reference values of body weight, stature, head circumference, and body mass index in Turkish Children. J Pediatr 2008;51:1-14.

44. Serra-Negra JM, Paiva SM, Bendo CB, et al. Verbal school bullying and life satisfaction among Brazilian adolescents: Profiles of the aggressor and the victim. Compr Psychiatry 2015;57:132-9.

45. Juvonen J, Graham S. Bullying in schools: The power of bullies and the plight of victims. Annu Rev Physiol 2014;65:159-85.

46. Wang I, Iannotti RJ, Nansel TR. School bullying among adolescents in the United States: Physical, verbal, relational, and cyber. J Adolescent Health 2009;45:368-75.

47. Aboud F, Miller L. Promoting peer intervention in name-calling. S Afr J Psychol 2007: 803-19.

48. Kartal H, Bilgin A. The perceptions of elementary students about the reasons for bullying. Gaziantep University I Soc Sci 2012;11:25-48.

49. Lemstra ME, Nielsen G, Rogers MR, Thompson AT, Moraros IS. Risk indicators and outcomes associated with bullying in youth aged 9-15 years. Can J Public Health 2012;103:9-13.

50. Liu X, Chen G, Yan J, Luo J. Weight status and bullying behaviors among Chinese school-aged children. Child Abuse Negl 2016;52:11-9.

51. Kovalskys I, Rausch Herscovici C, Indart Rougier P, Anez Ev, Zonis LN, Orellana L. Childhood obesity and bullying in schools of Argentina: Analysis of this behaviour in a context of high prevalence. J Childhood Obesity 2016;1:3-11.

52. Tippett N, Wolke D. Socioeconomic status and bullying: A meta-analysis. AM J Public Health 2014;104:48-59.

53. Ergün N. The investigation of peer bullying according to school, family and demographic variables in early adolescents. (Postgraduate Thesis). Hacettepe University, Education Sciences Institute, Ankara, 2015. Available date: 23.10.2015. file:///C:/ Users/server/Downloads/394827.pdf

54. Aküzüm $C$, Behçet $O$. The most common seen violence cases in terms of views of managers and teachers at schools, reasons and solving advices. Ekev Academi I 2015;61:1-30.

55. Álvarez-García D, García T, Núñez JC. Predictors of school bullying perpetration in adolescence: A systematic review. Aggress Violent Behav 2015;23:126-36.

56. Yang SI, Stewart R, Kim JM, et al. Differences in predictors of traditional and cyber-bullying: A 2-year longitudinal study in Korean school children. Eur Child Adolesc Psyhiatry 2013;22:30918

57. Magklara K, Skapinakis P, Gkatsa T, et al. Bullying behaviour in schools, socioeconomic position and psychiatric morbidity: A cross-sectional study in late adolescents in Greece. Child Adolesc Psychiatry Ment Healts 2012;6:1-13. 